\title{
Modelling of marine base cation emissions, concentrations and deposition in the UK
}

\author{
M. Werner ${ }^{1}$, M. Kryza ${ }^{1}$, A. J. Dore ${ }^{2}$, M. Blaś ${ }^{2}$, S. Hallsworth ${ }^{2}$, M. Vieno ${ }^{2,3}$, Y. S. Tang ${ }^{3}$, and R. I. Smith \\ ${ }^{1}$ Department of Climatology and Atmosphere Protection, University of Wroclaw, Poland \\ ${ }^{2}$ Centre for Ecology and Hydrology, UK \\ ${ }^{3}$ School of GeoScience, University of Edinburgh, UK
}

Received: 30 June 2010 - Published in Atmos. Chem. Phys. Discuss.: 22 September 2010

Revised: 25 January 2011 - Accepted: 29 January 2011 - Published: 4 February 2011

\begin{abstract}
Base cations exert a large impact on various geochemical and geophysical processes both in the atmosphere and at the Earth surface. One of the essential roles of these compounds is impact on surface $\mathrm{pH}$ causing an increase in alkalinity and neutralizing the effects of acidity generated by sulphur and nitrogen deposition. During recent years anthropogenic emissions of base cations in the UK have decreased substantially, by about $70 \%, 78 \%, 75 \%$ and $48 \%$ for $\mathrm{Na}^{+}, \mathrm{Mg}^{2+}, \mathrm{Ca}^{2+}$ and $\mathrm{K}^{+}$, respectively, over the period 1990-2006. For the island regions, such as the UK, the main source of base cation particles is the aerosol produced from the sea surface. Here, the sea salt aerosol (SSA) emissions are calculated with parameterisations proposed by Mårtensson et al. (2003) for ultra fine particles, Monahan et al. (1986) for fine particles and Smith and Harisson (1998) for coarse particles continuously with a $0.1 \mu \mathrm{m}$ size step using WRF-modelled wind speed data at a $5 \mathrm{~km} \times 5 \mathrm{~km}$ grid square resolution with a $3 \mathrm{~h}$ time step for two selected years 2003 and 2006. SSA production has been converted into base cation emissions, with the assumption that the chemical composition of the particle emitted from the sea surface is equal to the chemical composition of sea water, and used as input data in the Fine Resolution Atmospheric Multi-pollutant Exchange Model (FRAME). FRAME model annual mean concentrations and total wet deposition at a $5 \mathrm{~km} \times 5 \mathrm{~km}$ grid resolution, are compared with concentrations in air and wet deposition from the National Monitoring Network and measurements based estimates of UK deposition budget. The correlation coefficient for wet deposition achieves high values $(R=0.8)$ for $\mathrm{Na}^{+}$and $\mathrm{Mg}^{2+}$, whereas for $\mathrm{Ca}^{2+}$ the correlation is poor $(R<0.3)$. Base cation concentrations are also represented well, with some overestimations on the west coast and underestimations in the centre of the land.
\end{abstract}

Correspondence to: $\mathrm{M}$. Werner (malgorzata.werner@uni.wroc.pl)

\section{Introduction}

Base cations enter the atmosphere from natural and anthropogenic sources. Sodium and magnesium originate mainly from sea salt, whereas an important source of calcium is wind blown dust from land areas. In Northern Europe wind blown dust from agricultural soils can contribute up to $40 \%$ of total calcium deposition. On average the anthropogenic contribution to base cations deposition in Europe is usually below $15 \%$ and is the largest for calcium (van Loon et al., 2005b).

Sea salt aerosol (SSA), which is the main source of base cations, especially for the island regions, exerts a large impact on various geochemical and geophysical processes and on the Earth's climate. It modifies the Earth's radiative budget, biogeochemical cycling, impacts on ecosystems and regional air quality (O'Dowed and de Leeuw, 2007). Sea salt aerosol particles can also alter cloud properties and lifetime and provide media for chemical reactions (e.g.: Gong et al., 1997; Murphy et al., 1998; Behnke et al., 1997). The primary marine aerosol is emitted from the water surface into the atmosphere directly as droplets with the composition of seawater enriched with chemical compounds, bacteria and viruses occurring in the upper water column and in the film covering the water surface. The reactions of sodium from the sea salt particles with nitric acid forms sodium nitrate, which is, in contrast to ammonium nitrate, not semi-volatile and needs to be accounted for in the (particulate) nitrogen budget (Tamm and Schulz, 2003). SSA contributes to the deposition of base cation and its deposition flux should be accounted for in ion balance calculations to assessment of the exceedances of the acid critical loads (van Loon et al., 2005a). Base cations, such as $\mathrm{Na}^{+}, \mathrm{Mg}^{2+}, \mathrm{Ca}^{2+}$ and $\mathrm{K}^{+}$ are important in the environment (NAEI, www.naei.org.uk) because deposition has an impact upon surface $\mathrm{pH}$ causing an increase in alkalinity and neutralizing the effects of acidity generated by sulphur and nitrogen deposition. Hence, sea

Published by Copernicus Publications on behalf of the European Geosciences Union. 
salt aerosols are essential components of atmospheric models at urban, regional and global scales (Gong et al., 1997).

Sea spray forms when winds and waves force air bubbles to burst at the sea surface (Woodcock, 1953). Winds also tear off wave crests to form larger drops, but these drops fall back to the ocean quickly. At the time of production sea spray contains all the components of sea water (about $96.8 \%$ of the mass is water and the rest is the sea salt, Jacobson, 2005). The radii of SSA particles range from below $0.1 \mu \mathrm{m}$ to over $1000 \mu \mathrm{m}$ (Lewis and Schwartz, 2004).

Sea spray production parameterisations have been developed by Monahan et al. (1986); Woolf et al. (1987); Andreas (1992); Wu (1992); Smith et al. (1993); Smith and Harisson (1998); de Leeuw et al. (2000); Mårtensson et al. (2003) and Gong (2003), among others. Existing models of drop emissions from the sea surface are based both on laboratory studies (e.g. Monahan et al., 1986; Monahan and van Patten, 1989; Mårtensson et al., 2003) as well as measurements (Smith et al., 1993).

Commonly used formulations for sea salt aerosol generation are primarily based on the relation between whitecap coverage and wind speed, although other variables such as sea surface temperature and salinity may also influence the flux (Mårtensson et al., 2003). A whitecap method is based on combining the parameterization of the whitecap cover using field experimental data and the production of sea-spray aerosol per unit whitecap area determined from laboratory experiments (Monahan et al., 1986). Mårtensson et al. (2003) determined their source function from bubble-mediated laboratory studies to determine the flux as a function of whitecap coverage and then incorporated Monahan's wind speed and whitecap relationship to produce flux estimates. De Leeuw et al. (2000) based their parameterization on surf zone experiments while Reid et al. (2001) used a concentration build-up method using aircraft measurements in an evolving internal boundary layer.

SSA source functions have already been included in atmospheric models but most of these studies are on a global scale (e.g. Gong et al., 1997; Witek et al., 2007; Gong, 2003) and only a few refer to regional scale in high resolution (Foltescu et al., 2005). Because of the limited availability of measurements of the chemical composition of aerosol, there is also a major problem with verification of these models. For example Foltescu et al. (2005) compared their regional model results against measurements from eight monitoring stations in two European countries.

In this paper, selected parameterisations schemes (Mårtensson et al., 2003; Monahan et al., 1986 and Smith and Harisson, 1998) have been used to calculate marine base cation emissions $\left(\mathrm{Na}^{+}, \mathrm{Mg}^{2+}, \mathrm{Ca}^{2+}\right.$ and $\left.\mathrm{K}^{+}\right)$for the UK domain for the years 2003 and 2006. Taking into account dehydration and chemical composition of marine aerosol, the mass of base cation compounds $\left(\mathrm{Na}^{+}, \mathrm{Mg}^{2+}\right.$, $\mathrm{Ca}^{2+}$ and $\mathrm{K}^{+}$) was calculated from the total mass of SSA. In order to calculate base cation concentrations and deposition over UK, estimations of natural land emissions of calcium were made. Soil emission of calcium was calculated using wind blown $\mathrm{PM}_{10}$ emissions provided by the NatAir project supported with information on percentage content of calcium in various types of soil. Anthropogenic land emissions were taken directly from the National Atmospheric Emissions Inventory.

The calculated maps of base cation emissions were used in the Fine Resolution Atmospheric Multi-pollutant Exchange model to obtain mean annual concentrations and wet and dry deposition of $\mathrm{Na}^{+}, \mathrm{Mg}^{2+}, \mathrm{Ca}^{2+}$ and $\mathrm{K}^{+}$at a resolution of $5 \mathrm{~km} \times 5 \mathrm{~km}$ for the British Isles. The modelled results were compared with measurements of base cation wet deposition and air concentrations from the National Monitoring Network, using an increased number of stations for the year 2006.

\section{Methodology}

\subsection{FRAME model}

The atmospheric transport model, FRAME (Fine Resolution Atmospheric Multi-pollutant Exchange) is used to assess the long-term annual mean air pollutant concentrations and deposition of base cation: $\mathrm{Na}^{+}, \mathrm{Mg}^{2+}, \mathrm{Ca}^{2+}$ and $\mathrm{K}^{+}$over the UK. FRAME has been previously used to model sulphur and nitrogen compounds, heavy metals and particulate matter (e.g.: Dore et al., 2007; Matejko et al., 2009; Kryza et al., 2010). Recently FRAME was further developed to allow sea salt and base cation modeling, with the aim to develop a complex tool supporting environmental policy in the UK. The fundamentals of the model are described by Singles et al. (1998), Fournier et al. (2004) Dore et al. (2007) and Vieno et al. (2010).

FRAME is a Lagrangian model which represents the main atmospheric processes taking place in a column of air moving along straight-line trajectories following specified wind directions. The model consists of 33 vertical layers of varying thickness ranging from $1 \mathrm{~m}$ at the surface and increasing to $100 \mathrm{~m}$ at the top of the domain (ApSimon et al., 1994; Singles et al., 1998). Vertical mixing is described using Ktheory eddy diffusivity, and solved with the Finite Volume Method (Vieno, 2006). The emission from anthropogenic sources was inserted into the model according to the height of stack. The marine and wind blown dust emissions of base cations were injected in the surface layer (first layer of the FRAME model).

Dry removal rates are calculated separately for four groups of particle sizes using the geometric mean size, with the middle point of $1.25 \mu \mathrm{m}, 3.75 \mu \mathrm{m}, 6.25 \mu \mathrm{m}$ and $8.75 \mu \mathrm{m}$. The higher deposition velocity applies to larger particles for which gravitational settling is more efficient. This is set according to the values proposed by Ruijgrok et al. (1995, 1997); Zhang et al. (2001); Nho-Kim et al. (2004); Seinfeld and Pandis (2006). 
Wet deposition is calculated with a scavenging coefficient and constant drizzle approach, using precipitations rates calculated from a measurement-based map of average annual precipitation. The amount of material removed in a time pe$\operatorname{riod}(\Delta t)$ is given by:

$\Delta c_{i}=c_{i}\left(1-e^{\lambda_{i} \Delta_{t}}\right)$

$\Delta \mathrm{c}_{i}$ - decrease in concentration of species $i$ due to removal by precipitation

$\lambda_{i}-$ scavenging coefficient

$\mathrm{c}_{i}-$ concentration of pollutants

The wet deposition flux to the surface is the sum of wet removal from all volume elements aloft, assuming that scavenged material comes down as precipitation. There is no separation between in-cloud and below-cloud processes and an averaged value of scavenging ratio $\left(\Delta_{i}\right)$ is used in the model. To produce scavenging coefficient $\lambda_{i}, \Delta_{i}$ is combined with the precipitation rate and the depth of the mixing layer $\Delta H_{\text {mix }}$ :

$\lambda_{i}=\left(\Delta_{i} P\right) / H_{\mathrm{mix}}$

An increased washout rate is assumed over hill areas due to the seeder-feeder effect. It is assumed that the washout rate for the orographic component of rainfall is twice that used for the non-orographic components (Dore et al., 1992). The domain of FRAME covers the British Isles with a grid resolution of $5 \mathrm{~km}$ and grid dimensions of $172 \times 244$.

Input pollutant concentrations at the boundary of the model domain are calculated with FRAME-Europe - a similar model which runs on the EMEP grid at $50 \mathrm{~km} \times 50 \mathrm{~km}$ resolution. Trajectories are calculated with different starting angles at a $1^{\circ}$ resolution, using directionally dependent wind speed and wind frequency roses.

\subsection{Meteorology}

The precipitation data used in FRAME comes from Meteorological Office national network (approximately 5000 stations). The data are used in the form of annual rainfall fields for the UK and Ireland, with a resolution of $5 \mathrm{~km} \times 5 \mathrm{~km}$, for the years 2003 and 2006. A higher annual precipitation amount is apparent along the western cost and at higher altitudes. However during the wetter year (2006), annual precipitation above $2000 \mathrm{~mm}_{\text {year }}{ }^{-1}$ occurs over wider areas of the hill regions.

Wind speed and wind frequency data are prepared using the radiosonde information, separately for each year of interest (Dore et al., 2006). In order to sample data from different geographical locations, seven stations were selected in the United Kingdom. The selection criteria for radiosonde data were the existence of a complete data set and geographical representation of the different areas of the UK. The highest wind speeds are observed from the south-west and lower from the east directions. The predominant wind directions for both years are from SW-W.

\subsection{Emission}

Emissions of base cations consist of land (anthropogenic and natural) and marine sources. Anthropogenic emissions of base cations are taken directly from the National Atmospheric Emissions Inventory (NAEI, www.naei.org.uk) for the years 2003 and 2006 (Fig. 1). The most significant anthropogenic contribution to base cation emission is from glass production, quarrying, cement and lime production industries. The main sources of calcium are combustion in the manufacturing industry sector and quarrying of limestone. For magnesium and potassium the main sources are emissions from fireworks and then quarrying of dolomite - for $\mathrm{Mg}^{2+}$ and iron and steel production or coal burning in power stations for $\mathrm{K}^{+}$. Sodium is mainly emitted during combustion in the manufacturing industry, sinter production in iron production, domestic and power station coal burning.

During the last two decades anthropogenic emissions of base cations in the UK have decreased significantly. For the years 1990-2006 the decrease was from $2.106 \mathrm{Gg}$ to $0.585 \mathrm{Gg}(0.595 \mathrm{Gg}$ in 2003$)$ for $\mathrm{Na}^{+}$, from $2.800 \mathrm{Gg}$ to $0.616 \mathrm{Gg}\left(0.669 \mathrm{Gg}\right.$ in 2003) for $\mathrm{Mg}^{2+}$, from $8.609 \mathrm{Gg}$ to $2.125 \mathrm{Gg}$ (2.559 $\mathrm{Gg}$ in 2003) for $\mathrm{Ca}^{2+}$, and from $2.422 \mathrm{Gg}$ to $1.249 \mathrm{Gg}(1.490 \mathrm{Gg}$ in 2003$)$ for $\mathrm{K}^{+}$.

According to the NAEI, inventories for base cations have been significantly revised since the first version of calculations, but the estimates are still subject to significant uncertainty. This is because they are based on emission estimates for $\mathrm{PM}_{10}$ (which are themselves uncertain), coupled with estimates of the chemical composition of the $\mathrm{PM}_{10}$ which add further uncertainty (www.naei.org.uk). The smallest uncertainty is expected for magnesium $(-40 \%$ to $+80 \%)$ and the highest for calcium $(-50 \%$ to $+100 \%)$.

Estimation of natural land emission of calcium (Fig. 2) was based on $\mathrm{PM}_{10}$ wind blown dust emission calculated in the frame of the NatAir project (Korcz et al., 2009; natair.ier.uni-stuttgart.de), and information about $\mathrm{Ca}^{2+}$ content in different types of soil. Wind blown dust is estimated with high uncertainty, because it is determined by number of factors, including wind speed, surface wetness and roughness (van Loon et al., 2005b). Uncertainty related with NatAir $\mathrm{PM}_{10}$ emission inventory is about $50 \%$ (van Harmelen et al., 2004, after Korcz et al., 2009). NatAir provides data with spatial resolution of $10 \mathrm{~km} \times 10 \mathrm{~km}$ and temporal resolution of $1 \mathrm{~h}$. The data was prepared for four years: 1997, 2000, 2001 and 2003. The spatial pattern of the emission for different years is similar, and changes are due to meteorological condition. The content of $\mathrm{Ca}^{2+}$ in the Earth's crust is $3.6 \%$, but in soils the mineral composition is different because of the process of soil formation (Lee et al., 1999). The 


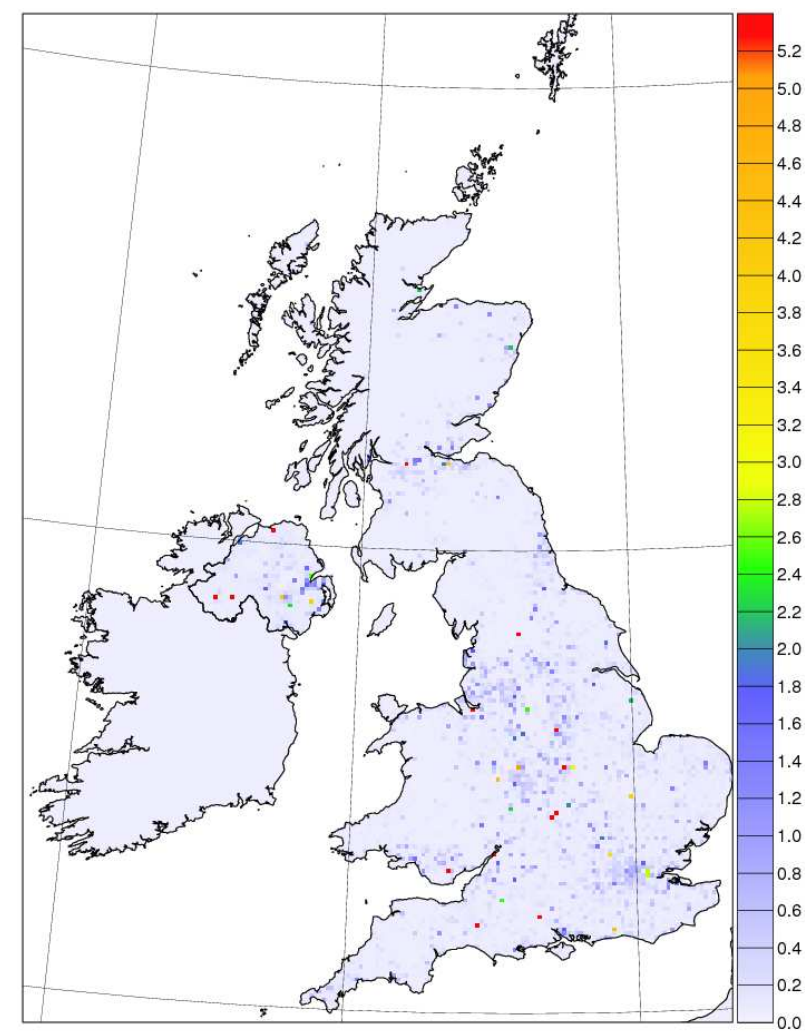

Fig. 1. Anthropogenic emission of calcium for the year 2006. Unit: $\mathrm{kg} \mathrm{ha}^{-1}$ year $^{-1}$.

information on $\mathrm{Ca}^{2+}$ content in soils was taken from Lee et al. (1999) for 106 soil types according to the FAO classification (Batjes et al., 2009; http://www.iiasa.ac.at/Research/ LUC/External-World-soil-database), and multiplied by an average $\mathrm{PM}_{10}$ wind driven dust emission for the years 1997 , 2000, 2001 and 2003. A four years average of UK wind blown dust emission of $\mathrm{Ca}^{2+}$ amounts $0.148 \mathrm{Gg}$ year $^{-1}$. The highest is for the year 2003-210 Mg, which is the driest year for the last period.

Calculation of base cation emissions maps of $\mathrm{Na}^{+}, \mathrm{Mg}^{2+}$, $\mathrm{Ca}^{2+}, \mathrm{K}^{+}$from the sea surface is one of the principal aims of this paper. Sea spray droplets come in three varieties: film droplets, jet droplets and spume droplets. Film $(0.5-5.0 \mu \mathrm{m})$ and jet droplets $(3-50 \mu \mathrm{m})$ derive from the same process: the bursting of air-entrained bubbles from oceanic whitecaps formed during the breaking of wind-induced waves (Mårtensson et al., 2003; Zhang et al., 2005). Spume droplets $(>20 \mu \mathrm{m})$ are derived from wind shear which tears the droplets directly from the wave crests (Andreas, 1998). The continuous impact of the wind to the sea surface results in wave breaking. Breaking waves are visualized by oceanic whitecaps, covering a limited part of the sea surface, typically $10 \%$ for wind speeds of $10 \mathrm{~m} \mathrm{~s}^{-1}$ (Wu, 1979). The relationships between the concentrations of sea-salt aerosol mass in the air and whitecap cover and wind speed were discovered

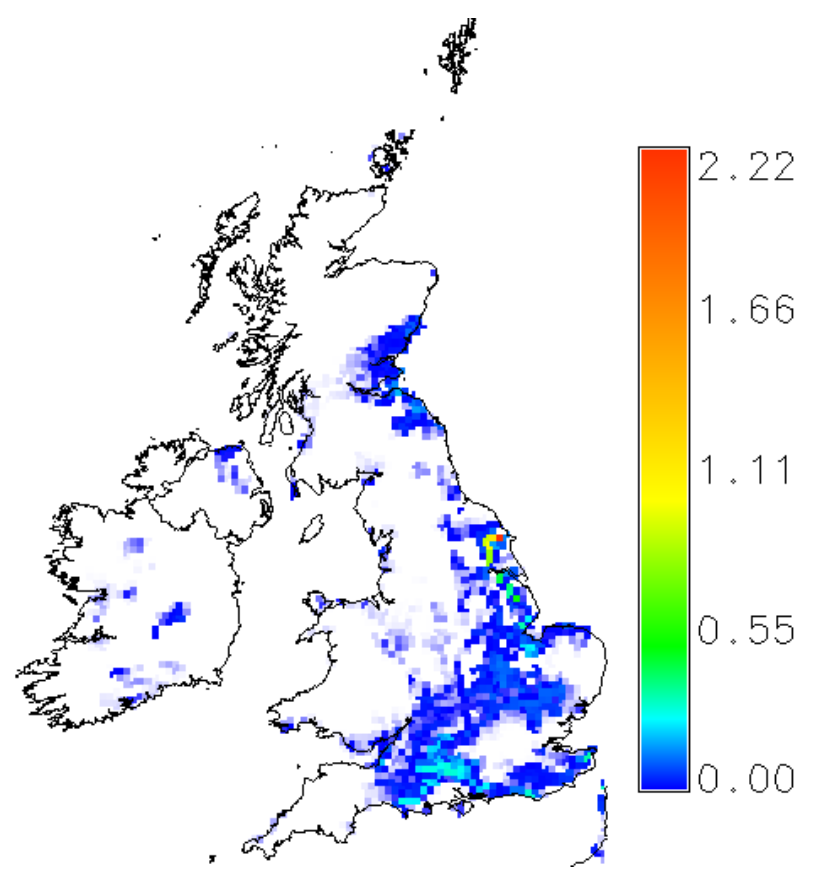

Fig. 2. Wind driven dust emission of calcium. An average for the years 1997, 2000, 2001 and 2003. Unit: $\mathrm{kg} \mathrm{ha}^{-1}$ year $^{-1}$.

in the 1950s (Woodcock, 1953). This dependence is very commonly used in SSA production formulas. The empirical equation, which is used in SSA formulations, for the whitecap cover ( $W$ in percent) as a function of the wind speed is presented by Monahan and O'Muircheartaight (1980):

$W=3.84 \times 10^{-4}\left(U_{10}^{3.41}\right)$

The equation is used directly in the form given above by Mårtensson et al. (2003) and in a modified form by other authors of SSA particle parameterisations.

The number of drops produced depends on the size of the bubble (Blanchard, 1963). The size of the jet drops is about $1 / 10$ of the initial bubble diameter size which places the jet drops in the super-micrometer aerosol size range. Film drops appear as a sub-micrometer aerosol (Woolf et al., 1987) and they can be up to several hundred per bubble and increase in number with diameter size of the bubble (Blanchard, 1963).

De Leeuw et al. (2000) illustrate that the source function of Monahan et al. (1986) applies best to particles with diameters below $10 \mu \mathrm{m}$ at formation, whereas the formulation proposed by Smith et al. (1993) gives better results for larger particles. Hoppel et al. (2002) also recommend a combined source function using Monahan et al. (1986) and a modified version of Smith et al. (1993). Foltescu et al. (2005) recommend the Monahan and Smith parameterisation, as discussed above, but for the smallest particles (below $0.8 \mu \mathrm{m}$ radius) suggest use of Mårtensson et al. (2003). Gong (2003) modified Monahan's source function to account for the observed decrease in the particle concentration for particles smaller 
than $0.1 \mu \mathrm{m}$ radius. Formulations comparison of a representative expression for the "whitecap method", made by Clarke et al. (2006), show that they lie within, approximately, a factor of 2 .

The primary SSA source function describes the surface flux (typically at $10 \mathrm{~m}$ above the ocean) of sea-spray aerosol, i.e. the number of droplets produced per unit surface area and per unit time. Being hygroscopic, SSA changes size as the ambient relative humidity changes. Sea-salt generation functions are usually given in the form of a continuous particle-size distribution (the amount of emitted particles is dependent on particle radius) at a specific relative humidity (RH), e.g. RH $=80 \%$ denoted as $r_{80}$ (Monahan et al., 1986; Smith and Harrison, 1998) or at formation, denoted as $r_{0}$ (de Leeuw et al., 2000).

Particle radius may also be presented as a dry particle when the relative humidity is zero $\left(r_{\mathrm{dry}}\right)$. The formulation depends on the way the source function has been derived. The equilibrium droplet size equation is presented in Gong et al. (1997), after Gerber (1985), Zhang et al. (2005). As a rule of thumb, the Eq. (4) is used (O'Dowd and de Leeuw, 2007):

$r_{0}=2 r_{80}=4 r_{\text {dry }}$

The emissions of drops from breaking wave whitecaps and sea foam is quite well-known thanks to the laboratory studies of, e.g. Wu (1973) and Monahan et al. (1982). Mostly, the source functions are presented as power-law functions, and hence, at higher wind speeds, the emission of sea spray increase in greater proportions than the wind speed increase. In this project, to calculate the $\mathrm{PM}_{10}$ sea salt aerosol emission into the atmosphere, different parameterisations for three radius ranges were used.

For particles radius $\left(r_{80}\right)$ below $0.8 \mu \mathrm{m}$ the Mårtensson et al. (2003) parameterisation is applied.

$\frac{d F}{d \log D_{\mathrm{p}}}=3.84 \times 10^{-6} v_{\mathrm{h}, 10}{ }^{3.41}\left(A_{k} T_{\mathrm{w}}+B_{k}\right)$

$A_{k}=c_{4} D_{\mathrm{p}}{ }^{4}+c_{3} D_{\mathrm{p}}^{3}+c_{2} D_{\mathrm{p}}{ }^{2}+c_{1} D_{\mathrm{p}}{ }^{1}+c_{0}$

$B_{k}=d_{4} D_{\mathrm{p}}^{4}+d_{3} D_{\mathrm{p}}^{3}+d_{2} D_{\mathrm{p}}{ }^{2}+d_{1} D_{\mathrm{p}}{ }^{1}+d_{0}$

$F$ - particle flux $\left(\mathrm{m}^{-2} \mathrm{~s}^{-1}\right)$

$V_{\mathrm{h}, 10}-$ mean horizontal wind speed at $10 \mathrm{~m}$ height $\left(\mathrm{m} \mathrm{s}^{-1}\right)$

$T_{\mathrm{W}}-$ water temperature $(\mathrm{K})$

$D_{\mathrm{p}}$ - dry particle diameter $(\mu \mathrm{m})$

$A_{k}, \quad B_{k}$ - the polynomials for given size ranges with coefficients $c_{0}$ to $c_{4}$ and $d_{0}$ to $d_{4}$ reported in Maartensson et al. (2003).
For larger particles $\left(0.8<r_{80}<4.0\right)$ the sea salt generation function is taken from Monahan et al. (1986):

$$
\begin{aligned}
& \frac{\Delta F_{i}^{\text {spume }}}{\Delta r_{i}}=1.373\left|V_{\mathrm{h}, 10}\right|^{3.41}\left(1+0.057 r_{i}^{1.05}\right) \\
& \times 10^{1.19 e^{-B^{2}}} r_{i}^{-3} \\
& B=\left(0.38-\log _{10} r_{i}\right) / 0.65 \\
& F-\text { particle flux }\left(\mathrm{m}^{-2} \mathrm{~s}^{-1}\right)
\end{aligned}
$$

$V_{\mathrm{h}, 10}$ - mean horizontal wind speed at $10 \mathrm{~m}$ height $\left(\mathrm{m} \mathrm{s}^{-1}\right)$

$r_{i}$ - droplet radius $(\mu \mathrm{m})$ at a reference relative humidity of $80 \%$.

For particles larger than $4.0 \mu \mathrm{m}$ radius at $80 \%$ humidity, the Smith and Harrison (1998) parameterisation is used:

$$
\begin{aligned}
& \frac{\Delta F_{i}}{\Delta r_{i}}=0.2\left|V_{\mathrm{h}, 10}\right|^{3.5} e^{1.5 \ln \left(\frac{r_{i}}{3}\right)^{2}}+0.0068\left|V_{\mathrm{h}, 10}\right|^{3} e^{-\ln \left(\frac{r_{i}}{30}\right)^{2}} \\
& F \text { - particle flux }\left(\mathrm{m}^{-2} \mathrm{~s}^{-1}\right)
\end{aligned}
$$

$V_{\mathrm{h}, 10}$ - mean horizontal wind speed at $10 \mathrm{~m}$ height $\left(\mathrm{m} \mathrm{s}^{-1}\right)$

$r_{i}$ - droplet radius $(\mu \mathrm{m})$ at a reference relative humidity of $80 \%$.

The main input data indispensable to calculate the emissions are wind speed information at a $10 \mathrm{~m}$ altitude above the surface. This data was generated with WRF (Weather Research Forecast, www.wrf-model.org) model, at a $5 \mathrm{~km} \times 5 \mathrm{~km}$ grid square resolution, with a 3-hour time step. The WRF set up is described in Vieno et al. (2010). As noted above, to calculate the sea salt aerosol production $\left(\mathrm{PM}_{10}\right)$ emitted into the atmosphere, different parameterizations for three radius range are used. All formulations are calculated with a $0.1 \mu \mathrm{m}$ radius size step for particles.

The high spatial and temporal resolution of the WRF data has great influence on the results of base cation calculations, as high emissions of base cations occur during relatively short periods with strong wind. Figure 3 presents the number of particles (a) and the mass of particles (b) at definite size emitted per unit of time $(1 \mathrm{~s})$ and unit area $\left(1 \mathrm{~m}^{2}\right)$ for different wind speeds $\left(5,10,15\right.$ and $\left.20 \mathrm{~m} \mathrm{~s}^{-1}\right)$. The number of emitted particles increases by more than 100 times when changing the wind speed from 5 to $20 \mathrm{~m} \mathrm{~s}^{-1}$, and the emission mass will be greater by more than $2 \times 10^{4}$ 

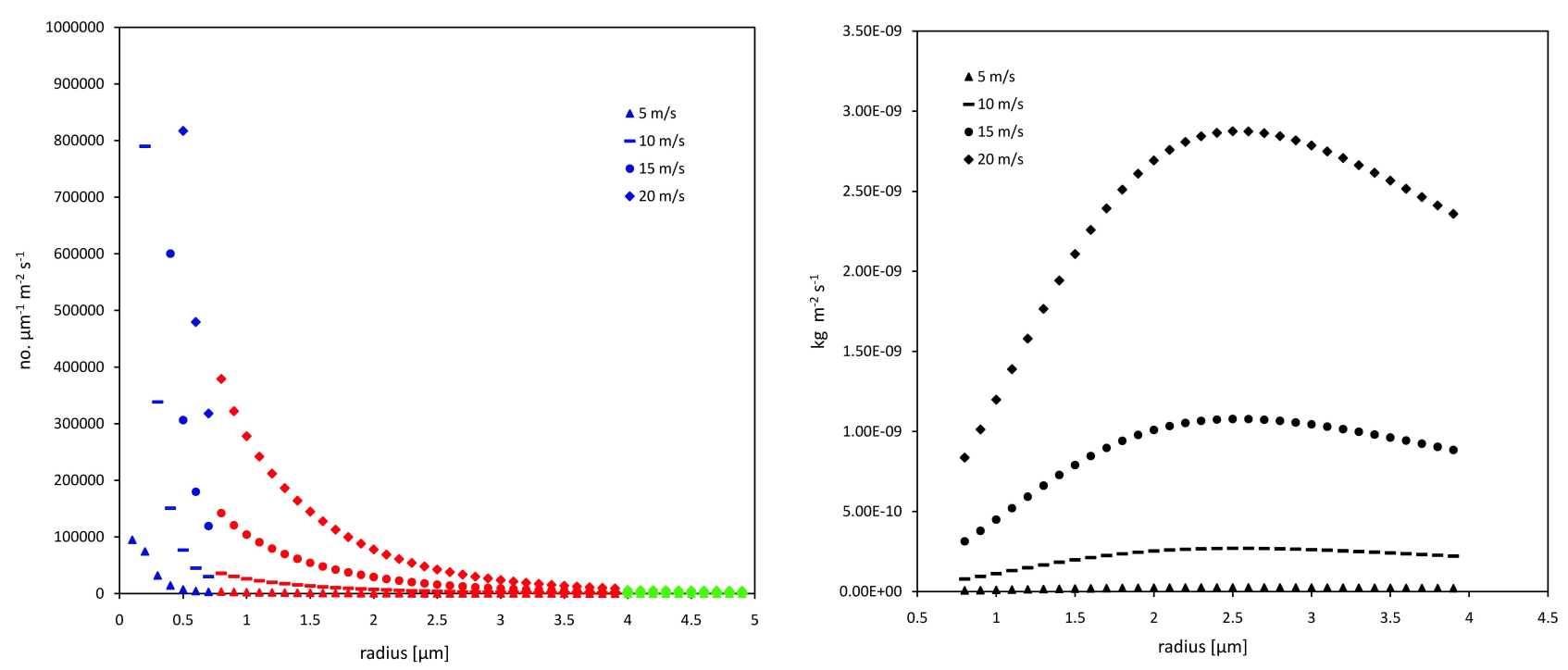

Fig. 3. Sea salt aerosol production: (A) number of particles for different wind speed for three parameterizations (blue, red, green: Mårtensson, Monahan, and Smith and Harrison parameterisations), (B) mass emitted for different wind speed for Monahan parameterisation.

To calculate $\mathrm{Na}^{+}, \mathrm{Mg}^{2+}, \mathrm{Ca}^{2+}$ from SSA emissions, it is assumed that at formation, the density of particles is the same as the density of sea water at $15^{\circ} \mathrm{C}$ and $3.5 \%$ salinity and the particles have the same ion composition as ocean water. The particles are assumed to be water containing a salinity representative of the relevant sea. The Monahan (for fine particles) and also Smith and Harrison (for coarse particles) equations used in the present work (defined above) give results for $80 \%$ humidity. Therefore the chemical composition is recalculated with the assumption that water evaporates and that radius at $80 \%$ humidity is equal to half of the radius at formation Eq. (1). To calculate the mass of $\mathrm{PM}_{10}$ sea salt particles it is assumed that they are spherical in shape. To get the dry mass of base cation $\left(\mathrm{Na}^{+}, \mathrm{Mg}^{2+}, \mathrm{Ca}^{2+}, \mathrm{K}^{+}\right)$the total mass of $\mathrm{PM}_{10}$ particles (ions, other species contained in the sea water, and water) is multiplied by the percentage content of a given ion. The mass percentages in sea water contents of particular compounds are the following: $\mathrm{Na}-$ $1.05 \%, \mathrm{Mg}-0.125 \%, \mathrm{Ca}-0.0398 \%, \mathrm{~K}-0.0386 \%$ (Seinfeld and Pandis, 2006). Table 1 sums up the emitted mass of base cations from land and anthropogenic sources. Spatial information on emission, calculated with the presented parameterisations, were exported to external files, and input off line to the FRAME model simulation.

\subsection{Model evaluation}

The model results for each year were evaluated by comparison with the measurements of air concentrations and wet deposition of $\mathrm{Na}^{+}, \mathrm{Mg}^{2+}$, and $\mathrm{Ca}^{2+}$. The base cation measurements are undertaken as a part of the UK Eutrophying and Acidifying Pollutants Monitoring Network. The CEH DELTA (Denuder for Long-Term Atmospheric sam-
Table 1. Emissions of base cation from land sources and import from sea region advected into the land (average for 2003 and 2006) [Gg].

\begin{tabular}{lrrr}
\hline Species & $\begin{array}{r}\text { Import from sea } \\
\text { region to UK }\end{array}$ & $\begin{array}{r}\text { Land } \\
\text { anthropogenic }\end{array}$ & Land \\
& 1133.2 & 0.59 & - \\
$\mathrm{Na}$ & 123.3 & 0.64 & - \\
$\mathrm{Mg}$ & 44.3 & 2.34 & 0.15 \\
$\mathrm{Ca}$ & & \\
\hline
\end{tabular}

pling) system, which was originally developed for long-term sampling of ammonia and ammonium (Sutton et al., 2001) was used. The system uses monthly sampling, with stable sampling rates of $0.3-0.41 \mathrm{~min}^{-1}$ achieved using a piston air pump, with air volumes being measured by a high sensitivity dry gas meter. The Delta sampler monitoring network was expanded from 12 to 30 stations during 2006, but some of the additional sites did not have a complete data set for this year. Data from two stations were removed due to insufficient monthly measurements following quality control.

There were no large changes between 2003 and 2006 in the total number of stations measuring wet deposition. Total mass of wet deposition was calculated using volume - weighted annual mean concentration $\left(\mathrm{Na}^{+}, \mathrm{Mg}^{2+}\right.$, and $\mathrm{Ca}^{2+}$ ) and amount of precipitation for each station. Measurements of $\mathrm{Ca}^{2+}$ and $\mathrm{Mg}^{2+}$ concentrations in water by ion chromatography have greater uncertainty than $\mathrm{Na}^{+}$due to their lower concentrations in solution. Uncertainty in measurements of $\mathrm{Na}^{+}$concentrations is estimated at approximately $( \pm 5 \%)$ and for $\mathrm{Ca}^{2+}$ and $\mathrm{Mg}^{2+}( \pm 15 \%)$. In addition it should be noted that the precipitation chemistry 

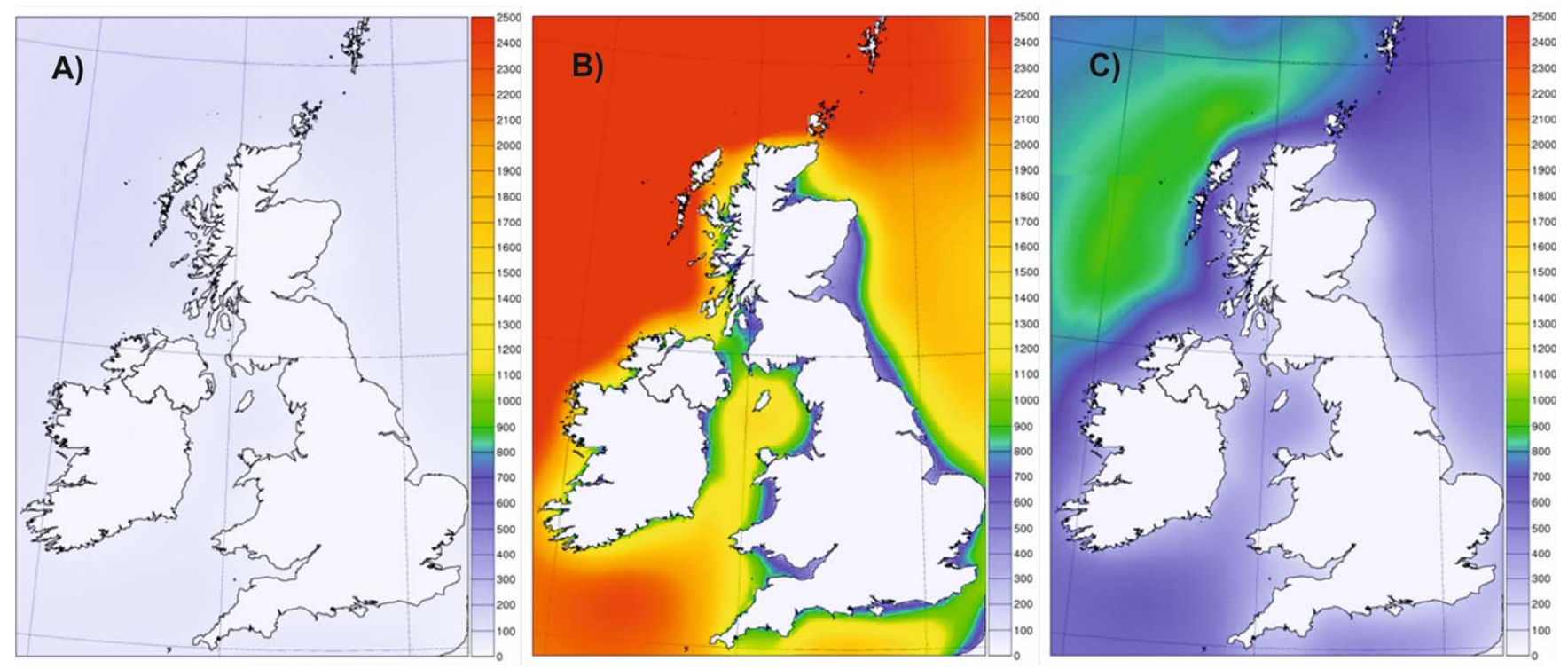

Fig. 4. Sea salt aerosol production of $\mathrm{PM}_{10}(\mathrm{RH}=80 \%)$ for the year 2006: (A) $r<0.8 \mu \mathrm{m}$, (B) $0.8 \mu \mathrm{m}<r<4.0 \mu \mathrm{m}$, (C) $r>4.0 \mu \mathrm{m}$. Units: $\mathrm{kg} \mathrm{ha}^{-1}$ year $^{-1}$.

monitoring network uses bulk samplers and can be subject to some dry deposition on the collector surface, which may lead to over-estimates of approximately $20 \%$ in ion concentrations in precipitation (Smith and Fowler, 2001).

For the year 2006, the FRAME national budgets of $\mathrm{Mg}^{2+}$ and $\mathrm{Ca}^{2+}$ dry and wet deposition were compared with the CBED (Concentration Based Estimated Deposition) measurement-interpolation technique. CBED wet deposition data were calculated from measurements gathered at the national monitoring networks of gas concentrations in air and ion concentrations in precipitation (Smith et al., 2000, 2001). The wet deposition model predicts deposition from the mapped actual annual rainfall (based on measurements interpolated from the UK Met Office precipitation monitoring network), estimated orographic rainfall, ion concentration in orographic rain and the feeder rainfall enhancement factor. The ion concentrations in seeder rainfall were interpolated over the country to estimate a value for each $5 \mathrm{~km}$ grid square. The interpolation from the annual rainfall-weighted mean concentration data at the sites uses kriging with an expotential variogram, a zero nugget and a sill and range determined from the individual year's observations. The feeder rainfall enhancement factor was assumed to have a value of 2 across the country. Dry deposition was calculated using a "big leaf" canopy resistance model combined with interpolation of measurements of base cation concentrations in air (Smith et al., 2000).

\section{Results}

\subsection{Primary marine particles and base cation emissions}

The highest values of total SSA emission are noted for regions with the highest wind speed, especially over the North Atlantic Ocean. For fine particles it is more than $2500 \mathrm{~kg} \mathrm{ha}^{-1}$ year $^{-1}(\mathrm{RH}=80 \%)$, and about $900 \mathrm{~kg} \mathrm{ha}^{-1}$ year $^{-1}$ for particles larger than $4.0 \mu \mathrm{m}$ (Fig. 4). The mass of ultra-fine particles for the whole area of the study domain is below $100 \mathrm{~kg} \mathrm{ha}^{-1}$ year $^{-1}$. The lowest mass is obtained close to the land, which is certainly connected to the wind friction and correspondingly lower wind speed. The calculated emissions results are converted to base cation mass according to the percentages given earlier. The domain average emissions from the sea, for individual base cations are as follows: $129,15,4.9$ and $4.7 \mathrm{~kg} \mathrm{ha}^{-1}$ year $^{-1}$ for 2003 and $145,17,5.5$ and $5.3 \mathrm{~kg} \mathrm{ha}^{-1}$ year $^{-1}$ for 2006, for $\mathrm{Na}^{+}$, $\mathrm{Mg}^{2+}, \mathrm{Ca}^{2+}, \mathrm{K}^{+}$, respectively.

\subsection{Base cation concentration and deposition}

The base cation emissions maps for the UK domain described above were used to run the FRAME model for the years 2003 and 2006. Additionally for the year 2006 two more simulations were run to compare the FRAME model with CBED (Concentration Based Estimated Deposition using measurement-interpolation) estimations. In order to establish the relative contributions of sea-salt and land based emissions, the first simulation was performed with land emissions only and the second one with sea emissions only. As 

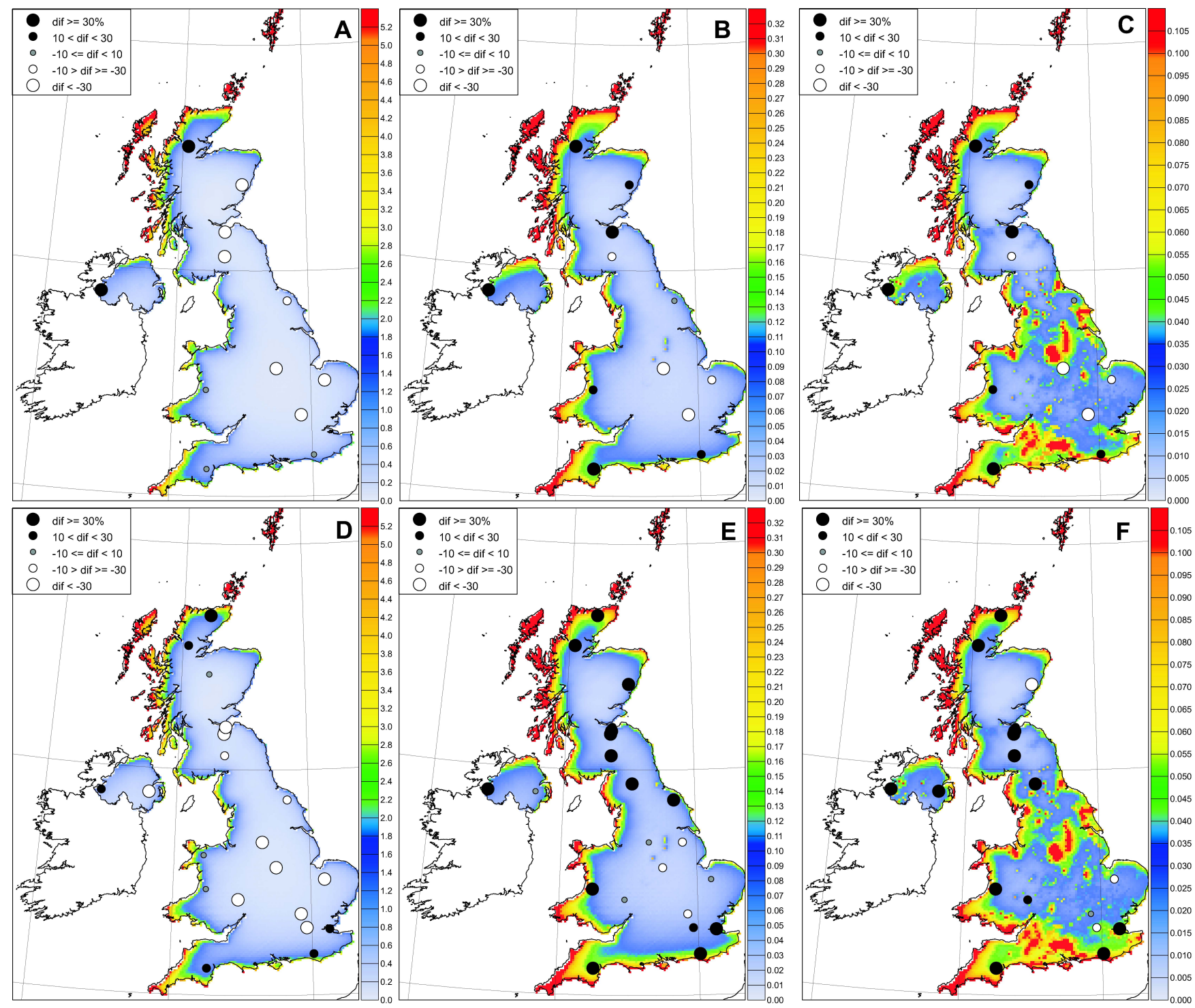

Fig. 5. Distribution of base cation concentrations $\left(\mu \mathrm{g} \mathrm{m}^{-3}\right)$ for the year 2003:(A) $\mathrm{Na}^{+}$, (B) $\mathrm{Mg}^{2+}$, (C) $\mathrm{Ca}^{2+}$ and $2006:(\mathbf{D}) \mathrm{Na}^{+}$, (E) $\mathrm{Mg}^{2+}$, (F) $\mathrm{Ca}^{2+}$. Errors for individual sites $(\%)$ are presented by dots $[($ model-measurement $) /$ measurement $\times 100]$.

a result of each run the average spatial distribution of $\mathrm{Na}^{+}$, $\mathrm{Mg}^{2+}, \mathrm{Ca}^{2+}$ and $\mathrm{K}^{+}$concentrations and total deposition for a year were calculated.

The distribution of base cation concentration near the surface is presented in Fig. 5 for all emission sources and in Fig. 6 for anthropogenic emission only. The concentrations are particularly high over oceanic regions with high production of SSA. A gradient in concentration is observed from the coastal regions towards low concentrations over land. Average yearly concentrations over the land domain were somewhat higher for 2006 than for 2003, and amount to: $2.17 \mu \mathrm{g} \mathrm{m}^{-3}$ of $\mathrm{Na}^{+}, 0.22 \mu \mathrm{g} \mathrm{m}^{-3}$ of $\mathrm{Mg}^{2+}, 0.08 \mu \mathrm{g} \mathrm{m}^{-3}$ of $\mathrm{Ca}^{2+}$ (Fig. 5). For the year 2003 these values were respectively: $1.89,0.19,0.07$ and $0.11 \mu \mathrm{g} \mathrm{m}^{-3}$. Average yearly con- centrations for measurement sites, which usually represent conditions for the centre of the land but not for the coast area, are lower than the average for the whole land area estimated by the FRAME model. For the year 2003 they amount to $0.80 \mu \mathrm{g} \mathrm{m}^{-3}, 0.06 \mu \mathrm{g} \mathrm{m}^{-3}$ and $0.05 \mu \mathrm{g} \mathrm{m}^{-3}$, respectively for $\mathrm{Na}^{+}, \mathrm{Mg}^{2+}$ and $\mathrm{Ca}^{2+}$.

The highest values of FRAME base cation concentrations are noted close to the coastal zone, especially in the western part of UK, which is the result of predominant westerly circulation. In these regions, concentrations of $\mathrm{Na}^{+}$, $\mathrm{Mg}^{2+}$, and $\mathrm{Ca}^{2+}$ can even exceed $5 \mu \mathrm{g} \mathrm{m}{ }^{-3}, 0.32 \mu \mathrm{g} \mathrm{m}{ }^{-3}$, $0.1 \mathrm{\mu} \mathrm{m}^{-3}$, respectively. For most areas of the UK the concentrations are in the range of 1.0 to $2.0 \mu \mathrm{g} \mathrm{m}^{-3}$ for $\mathrm{Na}^{+}, 0.05$ to $0.12 \mu \mathrm{g} \mathrm{m}^{-3}$ for $\mathrm{Mg}^{2+}$, and from 0.03 to $0.04 \mu \mathrm{g} \mathrm{m}^{-3}$ for 


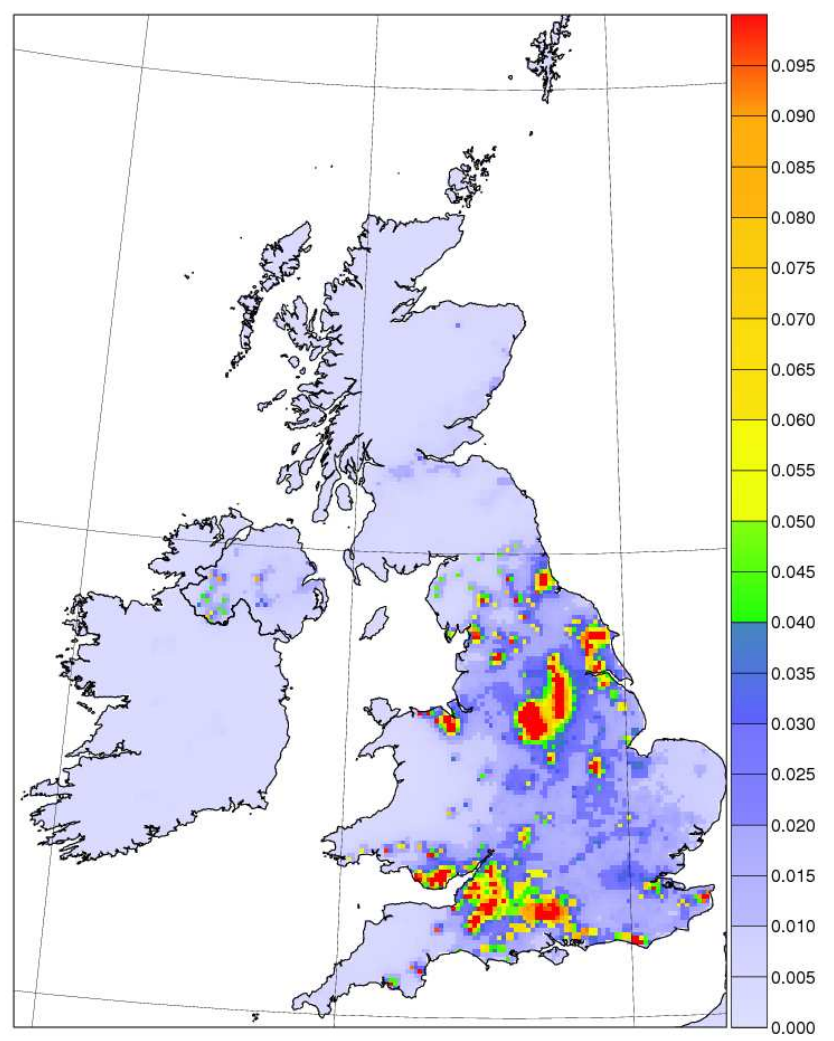

Fig. 6. Distribution of calcium concentrations $\left(\mu \mathrm{g} \mathrm{m}^{-3}\right)$ from land sources for the year 2006.

Table 2. The comparison of FRAME national budget $(\mathrm{Gg})$ of sea salt and non sea salt base cation $\left(\mathrm{Mg}^{2+}\right.$ and $\left.\mathrm{Ca}^{2+}\right)$ with $\mathrm{CBED}$ estimations for the year 2006.

\begin{tabular}{lcccl}
\hline simulation & \multicolumn{2}{c}{$\begin{array}{c}\text { land emissions } \\
\text { only }\end{array}$} & \multicolumn{2}{c}{$\begin{array}{c}\text { sea emissions } \\
\text { only }\end{array}$} \\
\hline \multicolumn{4}{c}{ FRAME regional deposition_budget $(\mathrm{Gg})$} \\
\hline dry & $\mathrm{Mg}$ & $\mathrm{Ca}$ & $\mathrm{Mg}$ & $\mathrm{Ca}$ \\
wet & 0.14 & 1.85 & 30.16 & 9.63 \\
& 0.37 & 2.55 & 99.39 & 31.75 \\
\hline dry & CBED estimations & $(\mathrm{Gg})$ \\
wet & 0.14 & 9.66 & 12.0 & 4.24 \\
\hline
\end{tabular}

$\mathrm{Ca}^{2+}$. Increased $\mathrm{BC}$ concentrations are also calculated for the centre of the land. This is especially evident for calcium in the region of Northern England and South-West England.

Wet deposition of $\mathrm{BC}$ reaches the highest values on the western coast, and over the high precipitation mountainous regions, where deposition of $\mathrm{Na}^{+}, \mathrm{Mg}^{2+}$ and $\mathrm{Ca}^{2+}$ exceeds $50 \mathrm{~kg} \mathrm{ha}^{-1}$ year $^{-1}, 6 \mathrm{~kg} \mathrm{ha}^{-1}$ year $^{-1}$ and $2.5 \mathrm{~kg} \mathrm{ha}^{-1}$ year $^{-1}$, respectively (Fig. 7). The substantial enhancement in wet deposition with altitude can be partially explained with the seeder-feeder enhancement mechanism, whereby rain falling from a higher level cloud (seeder cloud) layer passes through an orographically formed "cap cloud" (feeder cloud) over high terrain (Blaś et al., 1999). As it passes through the cap cloud, the rain scavenges cloud droplets, adding to the rainfall amount and ion content. The concentration is enhanced since cloud droplets are much smaller than rain drops and are thus far more concentrated for a given aerosol loading (e.g. Choularton et al., 1988; Dore et al., 1992; Inglis and Choularton, 2000). For the center part of the land, deposition is significantly lower, and mean value amounts to $14 \mathrm{~kg} \mathrm{ha}^{-1}$ year $^{-1}, 1.4 \mathrm{~kg} \mathrm{ha}^{-1}$ year $^{-1}$ and $0.5 \mathrm{~kg} \mathrm{ha}^{-1}$ year ${ }^{-1}$ of $\mathrm{Na}^{+}, \mathrm{Mg}^{2+}, \mathrm{Ca}^{2+}$ respectively.

\subsection{FRAME model evaluation}

The model results for each considered year were evaluated by comparison of the modelled values with measurements of concentrations and wet deposition of $\mathrm{Na}^{+}, \mathrm{Mg}^{2+}$, and $\mathrm{Ca}^{2+}$. For the year 2006, the FRAME national budget of $\mathrm{Mg}^{2+}$ and $\mathrm{Ca}^{2+}$ dry and wet deposition were compared with CBED estimations. Figure 8 illustrates the correlation with measurements of modelled $\mathrm{Na}^{+}, \mathrm{Mg}^{2+}$ and $\mathrm{Ca}^{2+}$ concentrations in air for the years 2003 and 2006. For both years most points are located above the 2:1 and below the 1:2 reference lines. The best fit is visible for sodium, with correlation coefficient at 0.6 for the year 2006, and the worst for $\mathrm{Ca}^{2+}$ for the same year. The spatial variability of model-measurement errors for all base cation air concentrations is similar. The model overestimates concentrations on the western coast and in Scotland, whilst underestimating in the center of the land (England). For sodium overestimations on the west coast are lower and underestimations in England are slightly higher than for other species.

Wet deposition is estimated by the FRAME model particularly well for sodium and magnesium, with correlation coefficient of 0.8 for both years (Fig. 9). Overestimation mostly occurs for higher values of deposition, which are measured on sites close to the western seaside, and the underestimation occurs in the hilly regions.

In the case of calcium whilst the model - measurements agreement is poor, also there is a significant difference between year 2003 and 2006. For 2003, the concentrations are generally underestimated, but for 2006 the overestimation is evident. At the same time a significant decrease in wet deposition occurs.

To evaluate the performance of FRAME it is also possible to compare model results with estimations of national budgets of dry and wet deposition of magnesium and calcium prepared by CBED for the year 2006 (Table 2). Both for $\mathrm{Mg}^{2+}$ and $\mathrm{Ca}^{2+}$ FRAME obtains lower deposition originating from land, with much lower values for calcium than CBED. Base cations import from the sea areas to 

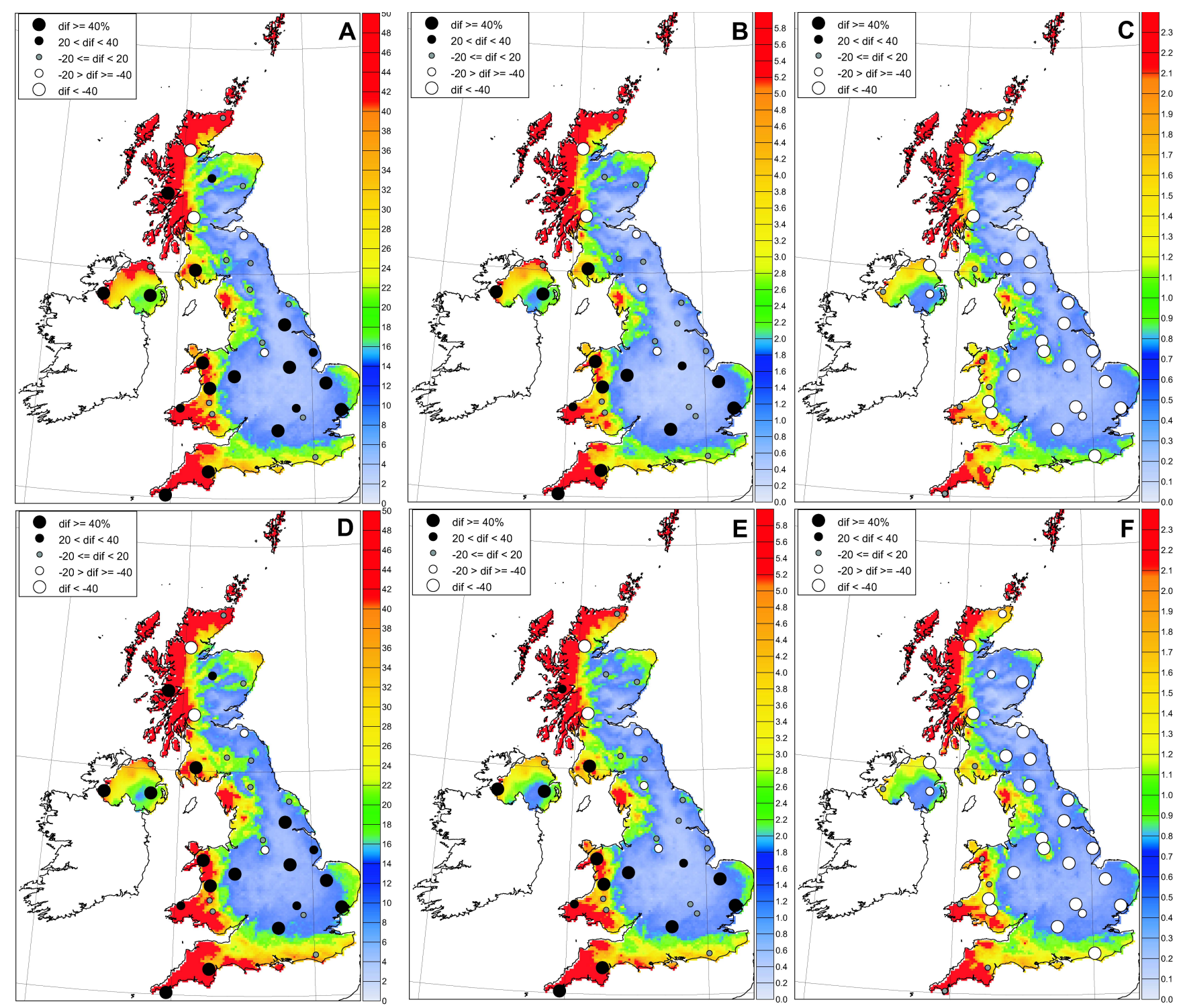

Fig. 7. Distribution of base cation wet deposition $\left(\mathrm{kg} \mathrm{ha}^{-1}\right.$ year $^{-1}$ ) for the year 2003: (A) $\mathrm{Na}^{+}$, (B) $\mathrm{Mg}^{2+}$, (C) $\mathrm{Ca}^{2+}$ and 2006: D) $\mathrm{Na}^{+}$, E) $\mathrm{Mg}^{2+}$, F) $\mathrm{Ca}^{2+}$. Errors for individual sites $(\%)$ are presented by dots [(model-measurement $) /$ measurement $\left.\times 100\right]$.

land calculated with FRAME amount to $1.148 \mathrm{Gg}$ for $\mathrm{Na}^{+}$, $0.124 \mathrm{Gg}$ for $\mathrm{Mg}^{2+}$, and $0.044 \mathrm{Gg}$ for $\mathrm{Ca}^{2+}$, for the year 2006. These values are dominant when compared with the contribution from land emissions (natural and anthropogenic sources), especially for sodium and magnesium. FRAME calculates that base cation emissions from the land sources contribute to $0.4 \%$ of total (land and sea emitted) deposition for magnesium and $10 \%$ for calcium. According to CBED estimations, land sources also contribute to $0.4 \%$ of total $\mathrm{Mg}^{2+}$ deposition but more than $50 \%$ of $\mathrm{Ca}^{2+}$. According to EMEP, wind blown dust in Northern Europe contributes up to $40 \%$ of total calcium deposition. In the case of sea emission, lower values of wet deposition and higher values for dry deposition are evident with FRAME. It is interesting to note that underestimation in wet deposition is not visible if the model is compared with station measurements (presented above). It should be noted that large uncertainties can also occur in the CBED calculation due to the subtraction process based on the measured $\mathrm{Na}^{+}$concentration used to separate the contributions of base cation emissions originating from land and sea.

\section{Summary and conclusions}

The main source of base cations, especially of sodium and magnesium, for the UK is the aerosol produced from the sea surface. For calcium, emission from wind blown dust and anthropogenic sources is also important. Anthropogenic 

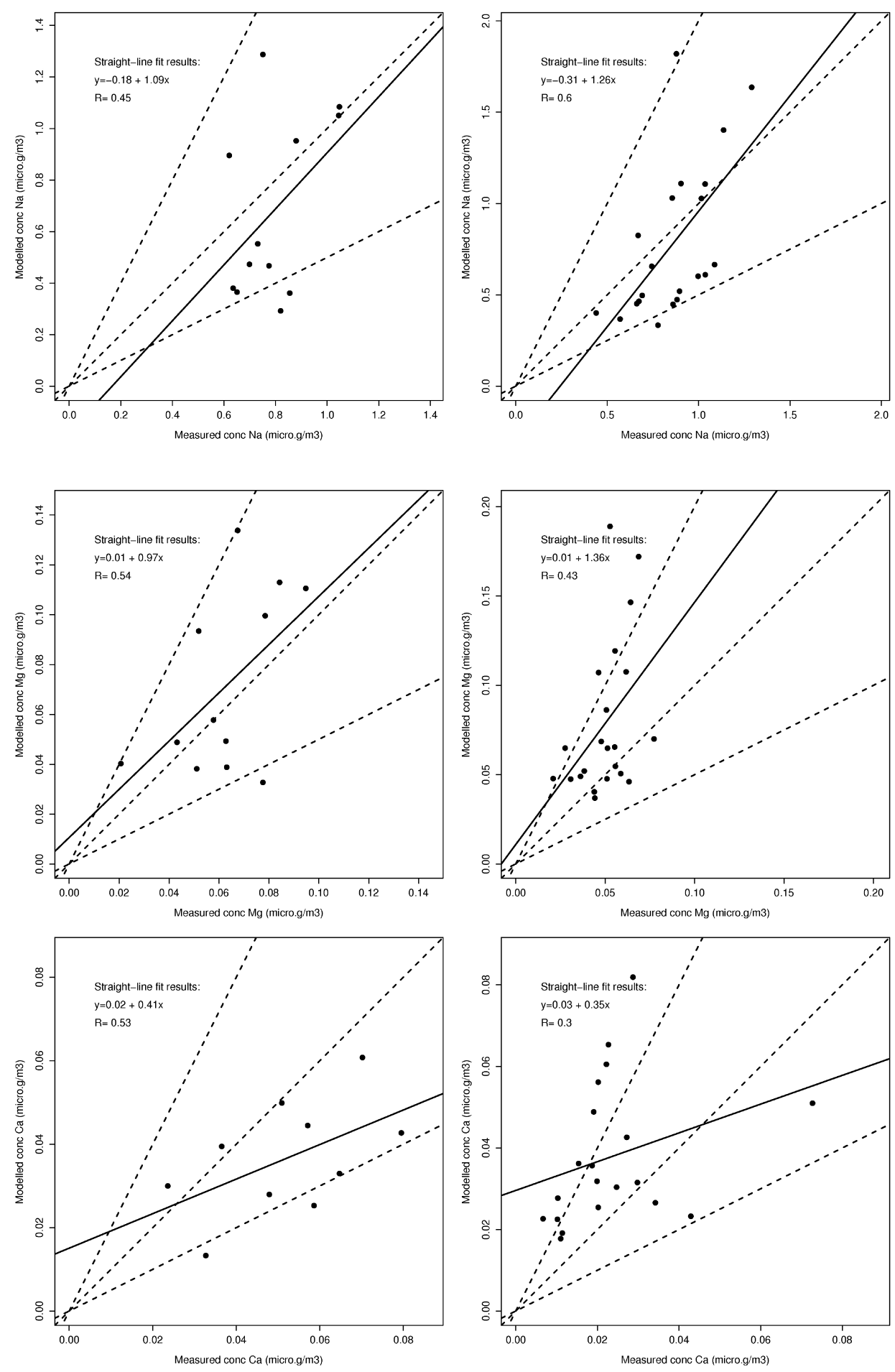

Fig. 8. Correlation of modelled and measured air concentrations of $\mathrm{Na}^{+}, \mathrm{Mg}^{2+}$ and $\mathrm{Ca}^{2+}$ for the year 2003 (left) and 2006 (right).

emissions of base cation have decreased by more than $70 \%$ for all analysed species for the period 1990-2006, and they amount to $0.585 \mathrm{Gg}$ for $\mathrm{Na}^{+}, 0.616 \mathrm{Gg}$ for $\mathrm{Mg}^{2+}$ and $2.125 \mathrm{Gg}$ for $\mathrm{Ca}^{2+}$ for the year 2006. According to the NatAir estimations, on average for one year, soil emission contributes $0.148 \mathrm{Gg}$ of $\mathrm{Ca}^{2+}$ which represents about $7 \%$ of total (soil + anthropogenic) land emissions.

The base cations of marine origin for UK region were calculated using three formulations of Mårtensson et al. (2003), Monahan et al. (1986) and Smith and Harrison (1998). All 

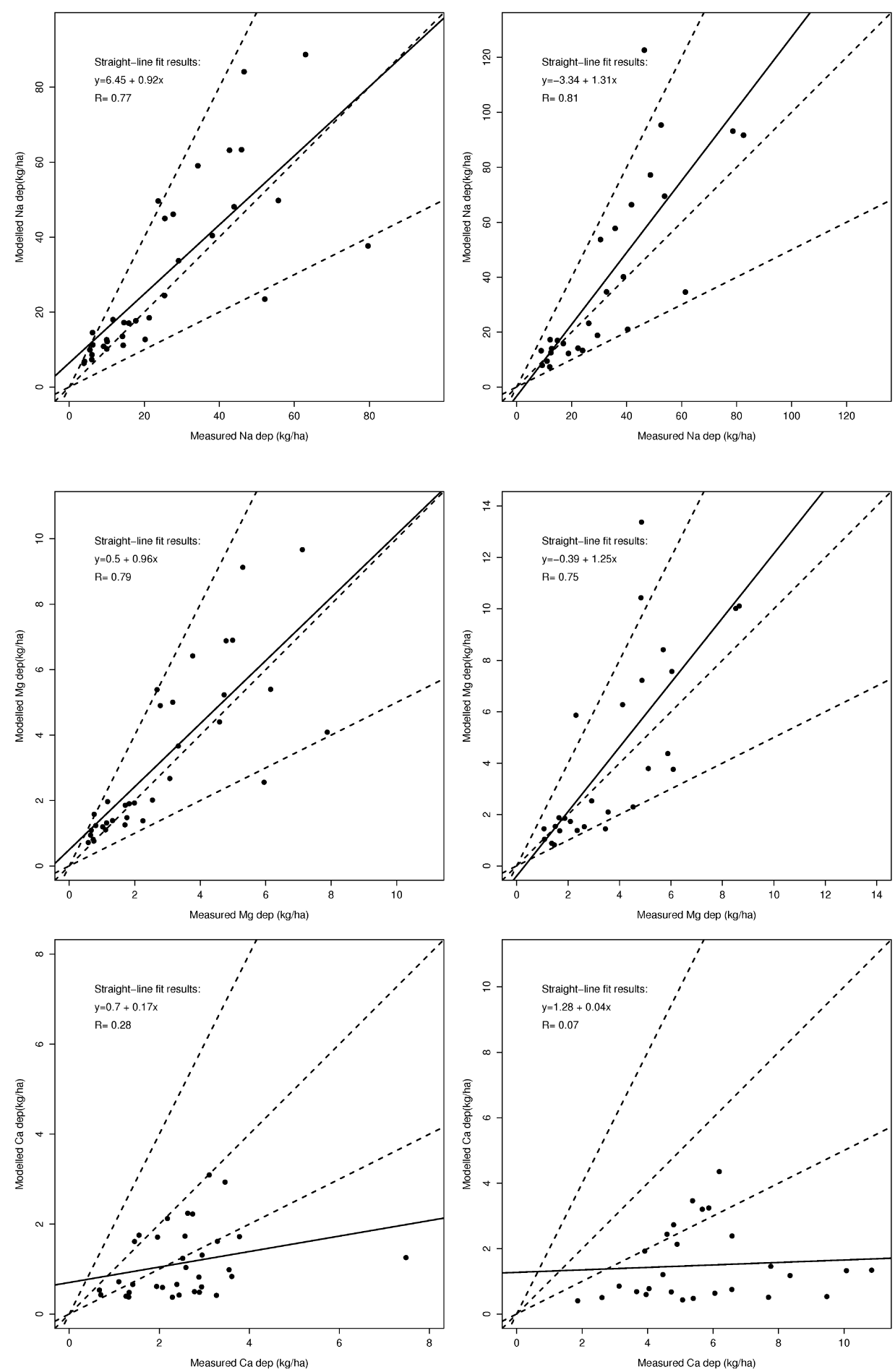

Fig. 9. Correlation of modelled and measured wet deposition of $\mathrm{Na}^{+}, \mathrm{Mg}^{2+}$ and $\mathrm{Ca}^{2+}$ for the year 2003 (left) and 2006 (right).

are based on WRF-derived information on wind speed at $10 \mathrm{~m}$ a.s.l. Additionally the Mårtensson function takes into account the temperature effects on the amount of production. The WRF wind speed data at a $5 \mathrm{~km} \times 5 \mathrm{~km}$ grid square resolution with a $3 \mathrm{~h}$ time step was used to calculate SSA emissions. The calculations were run with a $0.1 \mu \mathrm{m}$ size step for two selected years: 2003 and 2006. There is no large variation in spatial distribution between the two years, but the mass of SSA production is higher by more than $10 \%$ for 2006. 
All types of emissions are subject to uncertainty. Uncertainties related with NatAir estimations of $\mathrm{PM}_{10}$ amount to $50 \%$ but, additionally, it is necessary to include the uncertainty related to the content of $\mathrm{Ca}^{2+}$ in the different types of soil and quality of soil map. In the case of anthropogenic emission, the highest uncertainties are reported for $\mathrm{Ca}^{2+}(-50 \%$ to $+100 \%)$. As for $\mathrm{Na}^{+}$and $\mathrm{Mg}^{2+}$, for which the contribution of marine base cations is much higher than for $\mathrm{Ca}^{2+}$, also the FRAME model results are in a better agreement with measurements and CBED estimations than for $\mathrm{Ca}^{2+}$.

Spatial patterns of air concentrations of BC show the gradient from the coastal regions towards low concentrations over land. The wet deposition besides reaching high values close to the western coast, is also elevated in high rainfall hilly regions due to the seeder-feeder mechanism. The comparison of FRAME results with measurements has shown that the model is capable of predicting base cation concentrations and depositions for the UK region. The model results were found to be in good to reasonable agreement with measured wet deposition. Unfortunately, there are no measurements available for evaluation of the modeled dry deposition flux. The correlation coefficient for wet deposition achieves high values for $\mathrm{Na}^{+}$and $\mathrm{Mg}^{2+}$ for both years. Base cation concentration in air is also well represented by the model, with some overestimation on the west coast and underestimations in the centre of the land. Both for concentrations and wet deposition, worse results are obtained for calcium. Because there is the lowest contribution of marine source in total emission of $\mathrm{Ca}^{2+}$ than for remaining chemical components, we conclude that the problem is not in marine emission.

FRAME calculations of contribution of land emission to total deposition are in close agreement with CBED estimations for magnesium, where both FRAME and CBED calculate $0.4 \%$. In case of calcium, CBED estimates the contribution of land sources as 50\% and FRAME 10\%. The FRAME model calculates lower values of the national wet deposition budget than CBED, but the underestimation does not appear in model - measurements comparison. Future work should consider improvements in calculations of calcium land emissions and representation of the particle removal processes from the atmosphere in the FRAME model. This would concern both wet and dry removal processes, and especially detailed consideration of particle size influence effects.

Acknowledgements. This work was funded the Natural Environment Research Council and the Department for the Environment, Food and Rural Affairs.

Edited by: A. B. Guenther

\section{References}

Andreas, E. L.: A new sea spray generation function for wind speeds up to $32 \mathrm{~m} \mathrm{~s}^{-1}$, J. Phys. Oceanogr., 28, 2175-2184, 1998.

Andreas, E. L.: Sea spray and turbulent air-sea heat fluxes, J. Geophys. Res., 97(C7), 11429-11441, 1992.

ApSimon, H. M., Barker, B. M., and Kayin, S.,: Modelling studies of the atmospheric release and transport of ammonia - application of the TERN model to an EMEP site in eastern England in anticyclonic episodes, Atmos Environ., 28, 665-678, 1994.

Batjes, A., Dijkshoorn K., Engelen V., Fischer G., Jones A., Montanarella L., Petri M., Prieler S., Teixeira E., Wiberg D., and Shi X.: Harmonized World Soil Database, IIASA, Luxemburg, 2009.

Behnke, W., George, C., Sheer, V., and Zetzsch, C.: Production and decay of $\mathrm{ClNO}_{2}$ from the reaction of gaseous $\mathrm{N}_{2} \mathrm{O}_{5}$ with $\mathrm{NaCl}$ solution: bulk and aerosol experiments, J. Geophys. Res., 102, 3795-3804, 1997.

Blanchard, D. C.: The electrification of the atmosphere by particles from bubbles in the sea, in: Progr. Oceanogr., edited by: M. Sears, 73-202, Pergamon Press, New York, 1963.

Blaś, M., Dore, A. J., and Sobik, M.: Distribution or precipitation and wet deposition around an island mountain in southwest Poland, Q. J. Roy. Meteor. Soc., 125, 253-270, 1999.

Clarke, A. D., S. R. Owens, and Zhou J.: An ultrafine sea-salt flux from breaking waves: Implications for cloud condensation nuclei in the remote marine atmosphere, J. Geophys. Res., 111, D06202, doi:10.1029/2005JD006565, 2006.

Choularton, T. W., Gay, M. J., Jones, A., Fowler, D., Cape, J. N., and Leith, I. D.: The influence of altitude on wet deposition. Comparison between field measurements at Great Dun Fell and the predictions of the seeder-feeder model, Atmos. Environ., 22, 1363-1371, 1988.

De Leeuw, G., Neele, F. P., Hill, M., Smith, M. H., and Vignati, E.: Sea spray aerosol production by waves breaking in the surf zone, J. Geophys. Res., 105, 29397-29409, 2000.

Dore, A. J., Choularton, T. W., and Fowler, D.: An improved wet deposition map of the United Kingdom incorporating the seederfeeder effect over mountainous terrain, Atmos. Environ., 26A, 1375-1381, 1992.

Dore, A. J., Vieno, M., Fournier, N., Weston, K. J., and Sutton, M. A.: Development of a new wind rose for the British Isles using radiosonde data and application to an atmospheric transport model, Q. J. Roy. Meteor. Soc, 132, 2769-2784, 2006.

Dore, A. J., Vieno, M., Tang, Y. S., Dragosits, U., Dosio, A., Weston, K. J., and Sutton, M. A.: Modelling the atmospheric transport and deposition of sulphur and nitrogen over the United Kingdom and assessment of the influence of $\mathrm{SO} 2$ emission from the international shipping, Atmos. Environ., 41, 2355-2367, 2007.

Foltescu, V. L., Pryor, S. C, and Bennet, C.: Sea salt generation, dispersion and removal on the regional scale, Atmos. Environ., 39, 2123-2133, 2005.

Fournier, N., Dore, A. J., Vieno, M., Weston, K. J., Dragosits, U., adn Sutton, M. A.: Modelling the deposition of atmospheric oxidized nitrogen and sulphur to the UK using a multi-layer longrange transport model, Atmos. Environ., 38, 683-694, 2004.

Gerber, H. E.: Relative-humidity parameterization of the Navy aerosol model (NAM), NRL Rep. 8956, Natl. Res. Lab., Washington, DC, 1985.

Gong, S. L.: A paramterization of sea-salt aerosol source function for sub- and super-micron particles, Global Biogeochem. Сy., 
17(4), p. 1097, 2003.

Gong, S. L., Bartie, L. A., and Blanchet, J. P.: Modeling seasalt aerosols in the atmosphere. Model development, J. Geophys. Res., 102, 3805-3818, 1997.

Hoppel, W. A., Frick, G. M., and Fitzgerald, J. W.: Surface source function for sea-salt aerosol and aerosol dry deposition to the ocean surface, J. Geophys. Res., 107, 4382, doi:10.1029/2001JD002014, 2002.

Inglis, D. W. F. and Choularton, T. W.: Fine scale spatial variations in wet deposition, J. Atmos. Res., 55, 139-157, 2000.

Jacobson ,Z. M.: Fundamentals of atmospheric modeling, Cambridge University Press, 813 pp., 2005.

Korcz, M., Fudala, J., and Klis, C.: Estimation of wind blown dust emissions in Europe and its vicinity, Atmos. Environ., 43, 14101420, 2009.

Kryza, M., Werner, M., Blaś, M., Dore, A. J., and Sobik, M.: The effect of emission from coal combustion in nonindustrial sources on deposition of sulphur and oxidized nitrogen in Poland, J. Air Waste Manage., 60, 856-866, doi:10.3155/1047-3289.60.8.1, 2010.

Lee, D. S., Kingdom, R. D., Pacyna, J. M., Bouwman, A. F., and Tegen, I.: Modelling base cations in Europe - sources, transport and deposition of calcium, Atmos. Environ., 33, 2241-2256, 1999.

Lewis, E. R. and Schwartz, S. E.: Sea salt aerosol production. Mechanisms, methods, measurements, and models. Washington, DC: American Geophysical Union, 2004.

Mårtensson, E. M., Nilsson, E. D., de Leeuw, G., Cohen, L. H., and Hansson, H. C.: Laboratory simulations and parameterization of the primary marine aerosol production, J. Geophys. Res., 108(D9), 4297, doi: 10.1029/2002JD002263, 2003.

Matejko, M., Dore, A. J., Hall, J., Dore, C. J., Blaś, M., Kryza, M., Smith, R., and Fowler, D.: The influence of long term trends in pollutant emissions on deposition of sulphur and nitrogen and exceedance of critical loads in the United Kingdom, Environ. Sci. Policy, 12(7), 882-896, 2009.

Monahan, E. C.: Comment on "Bubble and aerosol spectra produced by a laboratory breaking wave", by R. J. Cipriano and D. C. Blanchard, J. Geophys. Res., 87, 5865-5867, 1982.

Monahan, E. C. and O'Muircheartaigh, I.: Optimal power-law description of oceanic white cap coverage dependence on wind speed, J. Phys. Oceanogr., 10, 2094-2099, 1980.

Monahan, E. C. and van Patten, M. A.: The climate and health implication of bubble - mediated sea-air exchange, Pub. Coccecticut Sea Grant Coll. Prog, 1989.

Monahan, E. C., Spiel, D. E., and Davidson, K. L.: in: Monahan, edited by: Mac Niocaill, E. C. G., Oceanic Whitecaps., Riedel, Norwell, MA, 167-174, 1986.

Murphy, D. M., Anderson, J. R., Quinn, P. K., Mclnnes, L. M., Brechtel, F. J., Kreidenweis, S. M., Middlebrook, A. M., Posfai, M., Thomson, D. S., and Buseck, P. R.: Influence of sea-salt on aerosol radiative properties in the Southern Ocean marine boundary layer, Nature, 392, 62-65, 1998.

Nho-Kim, E. Y., Michou M., and Peuch, V. H.: Parameterization of size-dependent particle dry deposition velocities for global modeling, Atmos. Environ., 38, 1933-1942, 2004.

O'Dowd, C. D. and de Leeuw, G.: Marine aerosol production: a review of the current knowledge, Phil. Trans. R. Soc, 365, 17531774, 2007.
Reid, J. H., Jonsson, H. H., Smith, M. H., and Smirnov, A.: Evolution of the vertical profile and flux of a large sea-salt particles in a coastal zone, J. Geophys. Res., 106 (D11), 12039-12053, 2001.

Ruijgrok, W., Davidson, C. I., and Nicholson, K. W.: Dry deposition of particles - implicationand recommendations for mapping of deposition over Europe, Tellus, 47, 587-601, 1995.

Ruijgrok, W., Tieben, H., and Eisinga, P.: The dry deposition of particles to a forest canopy: a comparison of model and experimental results, Atmos. Environ., 31, 399-415, 1997.

Seinfeld, J. H. and Pandis, S. N.: Atmospheric Chemistry and Physics, from Air Pollution to Climate Change, Wiley, New York, 1326 pp., 2006.

Singles, R.J., Sutton, M.A., Weston, K.J.: A multi-layer model to describe the atmospheric transport and deposition of ammonia in Great Britain, Atmos Environ, 32, 393-399, 1998.

Smith, R. I. and Fowler, D.: uncertainties in wet deposition of sulphur, W. A. and S. Pollution Focus, 1, 341-354, 2001.

Smith, M. H. and Harrison, N. M.: The sea spray generation function, J. Aerosol Science, 29 (Suppl. 1), 189-190, 1998.

Smith, M. H., Park, P. M., and Consterdine, I. E.: Marine aerosol concentrations and estimated fluxes over the sea, Q. J. Roy. Meteor. Soc., 119, 809-824, 1993.

Smith, R. I., Fowler, D., Sutton, M. A., Flechard, C., and Coyle, M.: Regional estimation of pollutant gas deposition in the UK: model description, sensitivity analyses and outputs, Atmos. Environ. 34, 3757-3777, 2000.

Sutton, M. A., Tang, Y. S., Miners, B., and Fowler, D.: A new diffusion denuder system for long-term, regional monitoring of atmospheric ammonia and ammonium, W. A. and S. Pollution Focus, 1, 145-156, 2001.

Tamm, S. and Schulz M.: Open-ocean aerosol composition obtained during 15 months on a North Sea ferry, Atmos. Environ., 37, S133-S14, 2003.

Witek, M. L., Flatau, P. J., Quinn, P. K., and Westphal, D. L.: Global sea-salt modeling: Results and validation against multicampaign shipboard measurements, J. Geophys. Res., 112, D08115, doi:10.1029/2006JD007779, 2007.

Woodcock, A. H.: Salt nuclei in marine air as a function of altitude and wind force, J. Meteorol., 10, 362-371, 1953.

Woolf, D. K., P. A. Boywer, and SMonahan E.C.: Discriminating between the film drops and jet drops produced by a simulated whitecap, J. Geophys. Res., 92, 5142-5150, 1987.

Wu, J.: Spray in the atmospheric surface layer: Laboratory study, J. Geophys. Res., 78, 511-519, 1973.

Wu, J.: Oceanic whitecaps and sea state, J. Phys. Oceanogr, 9, 1064-1068, 1979.

$\mathrm{Wu}, \mathrm{J}$.: Bubble flux and marine aerosol spectra under various wind velocities, J. Geophys. Res., 97(C2), 2327-2333, 1992.

van Harmelen, A. K., Denier van der Gon, H. A. C, Kok, H. J. G, Appelman, W. J., Visschedjik, A. J. H., and Hulskotte, J. H.: Particulate Matter in Dutch Pollutant Emission Register: State of Affairs; TNO-report, 428, 82, 2004.

van Loon, G. W. and Duffy, S. J.:Environ Chem.: A Global Perspective, Oxford University Press, 532 pp., 2005a.

van Loon, M., Tarrasón, L., and Posch, M.: Modelling Base Cations in Europe, Technical Report MSC-W 2, Norwegian Meteorological Institute, ISSN 0804-2446, 2005 b.

Vieno, M.: The use of an Atmospheric Chemistry-Transport Model FRAME over the UK and the development of its numerical and 
physical schemes, $\mathrm{PhD}$ thesis, University of Edinburgh, 2006.

Vieno, M., Dore, A. J., Stevenson, D. S., Doherty, R., Heal, M. R., Reis, S., Hallsworth, S., Tarrason, L., Wind, P., Fowler, D., Simpson, D., and Sutton, M. A.: Modelling surface ozone during the 2003 heat-wave in the UK, Atmos. Chem. Phys., 10, 79637978, doi:10.5194/acp-10-7963-2010, 2010.
Zhang, L., Gong S., Padro J., and Barrie L.: A size-segregated particle dry deposition scheme for an atmospheric aerosol module, Atmos. Environ., 35, 549-560, 2001.

Zhang, K. M., Knipping, E. M., Wexlera, A. S., Bhavee, P. V., and Tonnesen, G. S.: Size distribution of sea-salt emissions as a function of relative humidity, Atmos. Environ., 39, 3373-3379, 2005. 